\title{
Editor's Introduction: The Symposium on American Sociology
}

\author{
Lawrence T. Nichols
}

Published online: 7 March 2015

(C) Springer Science+Business Media New York 2015

The late Irving Louis Horowitz, whose Transaction Publishers produced The American Sociologist from 1987 through 2007, suggested that we bring out symposia in the journal. For this reason, among others, I am very happy to present to readers the set of papers that follows. I'm sure that Irving would feel likewise, given his passion for sociology and his concern about its prospects (best articulated in his book, The Decomposition of Sociology, which is cited by some of the authors here). Special thanks to Steve Turner, who first suggested this project, and to our quartet of commentators: Katelin Albert, Peter Baehr, Neil Gross and Eleanor Townsley. Having heard earlier versions of their papers at last summer's American Sociological Association conference, I know how deeply they care about the issues raised in Steve's book. Steve, of course, as the author and instigator, deserves the opportunity to "bat last" and offer a rejoinder.

I would also like to join the conversation. Rather than enter the give-and-take of the five papers that follow, however, I will offer some independent reflections arising from my own reading of American Sociology: From Pre-Scientific to Post-Normal as well as from my own experience of studying and practicing sociology for several decades. I was deeply affected by some of the events that Steve Turner describes, such as the extremely tough market conditions that resulted in me teaching on a part-time and temporary basis, without health benefits or pension savings, for the better part of a decade, mostly in the Boston area. In some respects, this was an unusually rich experience, since I taught at diverse institutions, ranging from two community colleges to several relatively small state colleges and to large public and private universities. But it was an experience of professional marginality (e.g., I was generally not allowed to attend department meetings) and insecurity that has helped me understand the struggles of many non-tenure-track colleagues in the field today. It was also an era in which sociology became highly politicized, not only in terms of its intellectual perspectives but also in terms of interpersonal relations. Happily, the situation has improved, and the process by which that came about is perhaps another historical narrative waiting to be written. 
I will limit my remarks to several basic points, all of which, I hope, are related to Steve's analysis of events over the past century and a quarter.

\section{External Audiences Will Continue to Matter}

Sociologists of virtually any theoretical persuasion will very likely agree with the premise that human action and interaction is always situated, and that definitions of situations by participants (which may differ greatly) are highly consequential. Another way of putting this is to say that sociological understanding must always be contextual or contextualized understanding. Histories of the field, however, as critics have often pointed out, tend toward biographical accounts of the activities of major figures, whether those are understood as "Marx, Durhkeim and Weber" or "Harriet Martineau and the Jane Addams Circle" (Deegan 1990; Lengerman and Brantley 1997; Hill and Drysdale 2003) or in other ways.

Our grasp of historical events changes and deepens when we consider the actions of sociologists as responses to what they perceived as the demands of contemporary contexts. Where academic sociology is concerned, a very strong case can be made that what is often criticized as the "scientism" of the 1920s was a response to demands by significant and powerful audiences that sociology "prove itself as a science," and demonstrate once and for all that it was more than mere political and socialistic ideology. Sadly, many critiques of figures such as Robert Park, F. Stuart Chapin and William F. Ogburn seem to miss this point and thus portray these earlier colleagues as suffering from false consciousness, or as actually malicious.

In more recent decades, departments of sociology have again come under external scrutiny and have sometimes served as easy targets for budget cuts. I'm not entirely certain whether anyone has compiled a complete listing, but certainly there have been at least several closures of U.S., sociology departments since 1980. Likewise significant were cases in which sociology departments had "close calls," even at very prestigious institutions where the subject had been long established. Perhaps the most publicized case was that of Washington University in Saint Louis, Missouri, where the department (where Irving Louis Horowitz had once worked) was shut down in 1991. Some years ago, I spoke with a former member of that department, who had lost his position as a result of the closure, and asked whether it was true that faculty in the Senate had supported the administration's action in abolishing the department. He told me that was indeed the case, and that the most aggressive critic during the final debate was a professor of biology who asserted that, "Sociology is an empty set" (which means, I suppose, that it has no real identity). The asymmetry here is significant, in the sense that no one can credibly call biology an "empty set" as a pretext for its closure.

The Washington University affair took place nearly a quarter-century ago. Nevertheless, the issues involved remain enormously important. In recent times, the former president of Harvard, Larry Summers, openly ridiculed sociology for celebrating what he regards as its focus on relatively trivial research. This is not to say that Summers was right, any more than the anti-sociology faculty at Washington University were right. I don't believe they were. But these events should warn us against complacency. We cannot simply do as we please-or, rather, if we do so we may suffer serious consequences. 
Sociology, as an academic enterprise, must retain the good will of its peers, if it is to survive and prosper. And that must mean producing creative work that commands respect, that "measures up against" what is done in other fields of learning. There must be discoveries and exciting ideas, which flow from an evolving and creative intellectual agenda. This in turn will require the fuller development of a "culture of excellence" in the field that overcomes the suspicion that to promote excellence is to endorse elitism and exclusion. Inclusiveness is a basic value, but it is not enough. The field needs to regain and reaffirm a commitment to "aim high" intellectually, and to recognize that intellectual excellence benefits all of us.

\section{Politics Posing as Science Will Not Be Viable}

During the past half-century, many sociologists in the U.S. seem to have moved away from the intellectual project of "building a science together" toward the political project of "building a movement for social change." An influential and symbolic event in this process was the publication of Howard Becker's 1967 article in the journal Social Problems, "Whose Side Are We On?" This analysis attacked the idea of objective, neutral and value-free knowledge, while also suggesting that knowledge in sociology is tied to partisan loyalties, whether conscious or unconscious. More recently, the related idea of "standpoint epistemology" has gained widespread acceptance, and has sometimes been used as a basis for claims to both separate, and superior knowledge that might be termed "knowledge for members only."

A serious danger here, in my judgment, is the inculcation of what I have elsewhere referred to as an "enemies mentality" in the field (Nichols 2012), which some would argue appears even in introductory textbooks and courses that tell students, in effect, that the conflict approach is the only adequate paradigm (Smith 2014). One highly influential expression of the attitude I am trying to describe is the genre of "critique," which may be stronger in sociology than in most, if not all, other fields. Considered as rhetoric, critique involves a double-move, namely: (1) the idealization of individuals and groups with which critics identify (e.g., the working poor or the underclass); and (2) the vilification of other groups with which critics do not identify (e.g., global corporations). The process is similar to what Harold Garfinkel (1956) described as the "dramatic contrast" between conformists and deviants in his influential article, "Conditions of Successful Degradation Ceremonies." In order to be effective, the contrast must be rendered as sharply and starkly as possible. This, however, arguably leads to a double stereotyping and a double distortion: groups with which critics align appear as, relatively speaking, perfect, at least for purposes at hand; while groups that critics reject appear as inherently evil and incapable of goodness.

All of this, I think, is related to Steve Turner's (2013) discussion of advocacy research, which he predicts will be a dominant feature of sociological work in the decades ahead. Advocacy, of course, is a process typical of courtroom encounters. In criminal cases, the prosecution advocates on behalf of society as a whole (at least in principle), while the defense advocates on behalf of the accused. Both sides engage in fact-finding practices that might be regarded as scientific or at least quasi-scientific, but both do so in support of already established conclusions (i.e., either "the accused is guilty" or else "my client is innocent"). Judges and jurors decide which view seems 
more credible, more fully grounded in relevant evidence and logic. This approach is defensible on practical and ethical grounds, but it is not "science" as that activity has been traditionally understood (Weber 1946; Merton 1973).

For me, the key point is this: science must consider all relevant evidence, whether portions of that evidence support a favored interpretation or not. Science, in other words, stands for "the whole truth." Scientists must be willing to be surprised, and also to be disappointed, insofar as they are emotionally attached to a particular viewpoint. Albert Einstein is an interesting exemplar. As many historians and biographers have noted, Einstein resisted the emerging paradigm of quantum mechanics because of its emphasis on probability rather than causality. In a famous quote, he commented that, "The old one (god?) does not play dice with the universe." Committed to this view, Einstein devised a considerable number of experimental designs intended to disprove the quantum approach. All of these, however, failed. Importantly, Einstein published his failures and acknowledged his inability to refute the new theory. This is true science and, one might even say, science at its best. Truth, not personal loyalties, comes first, even when that truth is distasteful.

To the extent that scientific work becomes politicized, this approach becomes impossible, or very nearly so. For when science is politicized - whether "to the right" or "to the left," whether in terms of "Aryan racial superiority" or "Marxist-Leninist dialectical materialism" - the practical result is the same: all the important answers are known in advance. Just as in the advocacy of prosecutors and defense attorneys, politicized scientists seek to prove what they believe they already know. But in contrast to courtroom procedures, they do not submit to the opinions of judges or jurors, but remain committed to a particular view based on partisan loyalties. Their orientation is to "carry on the struggle."

If sociologists were to say openly, 'Everything we do is based on partisanship,' they would lose credibility both within academia and within society more generally. And thus there is a tendency to engage in what might be called a "disguised partisanship," where research designs and data collection and data analysis are all undertaken with an eye toward attaining a predetermined conclusion, but where an effort is made to preserve a scientific appearance. However, as Erving Goffman (1959) remarked, once a show is given away, it is extremely difficult to restore the previous illusion. In other words, if external audiences perceive that sociology is merely partisan advocacy, they will simply refuse to recognize it as science, and will tend to discredit it. Its results will not be regarded as authoritative or binding, and, in a worst case scenario, outsiders will reject it entirely as unreliable.

The philosopher Plato, many centuries ago, presented an influential analysis of varieties of knowledge and their relative credibility. At the low end of the scale was sense impression, which he considered highly unreliable, and at the high end was the most certain truth, arrived at via philosophical dialectic. Toward the lower end was opinion or subjective belief, something that might appear these days in blogs or editorials or op-ed essays. What I am trying to say, in other words, is that the more we politicize our work, the more we turn toward advocacy and away from traditional science, the more we become mere bloggers and essayists whose work can be rejected out of hand by those holding different opinions. This is not a future worth pursuing, even if done for noble motives. The ethos of "whose side are we on" will tend to destroy sociology as a credible academic enterprise comparable to its peer disciplines. 


\section{Sociology Cannot Be "For Liberals Only"}

During the turbulent era of the 1960s and 1970s, when the conflict perspective reemerged and largely displaced the previously hegemonic consensus approach, a corresponding formula appeared: "the status quo is bad (i.e., unjust) and change is good." This view remains very influential today, despite being simplistic and arguably wrong, since change (e.g., environmental damage and destruction resulting from the industrial revolution) can be harmful as well as beneficial. At the same time, unless there is some basic goodness in the status quo (e.g., Constitutional rights to free speech and redress of grievances), there is no reasonable basis for believing that beneficial change is possible. What people really mean, I think, is that "improvement is always good."

The discourse of the 1960s and 1970s included three "C words" that echo in much sociological work today: capitalism, conservatism and critique. The first two are pejorative, and it is difficult to imagine sociologists getting up at a professional conference to praise either the capitalist economic system or conservative points of view, whether political (e.g., the Republican party) or religious (e.g., "the Christian right") or more generally social (e.g., opposition to abortion on demand). The third "C word," by contrast, has a positive aura for many in the field and is regarded as an impetus for change, as well as the basis of what Joe Feagin and Hernan Vera (2008) has termed "liberation sociology."

The apparent unwillingness of inability of sociologists to endorse either capitalism or conservative points of view can be explained in various ways. Self-selection, for instance, might be a key factor, especially for those who feel disadvantaged or oppressed, and who see in sociology a means to fight for changes from which they might personally benefit. In the same way, self-selection might operate if it is indeed the case that sociologists tell students from the time of their introductory courses that only liberal-minded people should enter the field. Meanwhile, social control processes in the profession might work to restrict or marginalize or penalize those with unacceptably "conservative" outlooks.

The elephant in the room is the contradiction between the discouragement or active suppression of conservative perspectives and the explicit embrace of "inclusiveness and diversity" in professional sociological associations. Critics might build a case that, while inclusiveness in terms of race and ethnicity, class, gender and sexual orientation is fine, the pious affirmations of diversity have little meaning if intellectual diversity and diversity of conscience are prohibited. Personal experience seems to demonstrate clearly that many sociologists have become very comfortable with a discipline that is "for liberals only," and wish it to remain so. Consequently, those whose opinions are not sufficiently liberal, or who experience doubt and ambiguity about liberal positions, tend to conceal their true thoughts and feelings.

These pattern of sociology being "for liberals only" is increasingly evident in the election of officers, especially for the top offices in ASA. I believe it is fair to say that anyone whose views seem more conservative than those expressed by ASA would be very unlikely either to be nominated or to be elected. During the past two decades, several presidents of ASA have been committed to strong "left" political positions, including both feminism and Marxism. None can be said to be on the political "right."

Such developments recall Michael Burawoy's observation (2005) that sociology has increasingly moved to the left, while American society has moved to the right. And this 
dynamic may well continue. Since "left" has increasingly been defined as "good," there does not seem to be any concern, at least in an organization such as ASA, that sociology could move too far leftward. Meanwhile, however, the increasing separation of sociology from public opinion in the U.S. must lead to credibility problems. The more sociology becomes merely "leftism," the less will the American public care about it.

Finally, if sociology can define itself as "on the left" and "for liberals only," then, by the very same logic, some other field - whether economics or political science or psychology — could define itself as "on the right' and "for conservatives only." In the same way that sociology may be actively filtering out anyone not considered liberal enough, such a discipline could actively filter out anyone not considered conservative enough.

It is worth recalling that even in the most liberal groups there are some members who are not quite as liberal, and that in the most conservative groups there are some who are not quite as conservative, who have liberal or "progressive" leanings, at least on particular issues. Emile Durkheim seems to have recognized this fundamental fact of life, in his famous discussion of the probability of deviance and punishment even in a society of angels, where tiny departures would seem like major breaches. The desire for a final victory either of liberalism or of conservatism is thus based on illusion. Meanwhile, ridding the world either of liberals or of conservatives would destroy diversity of thought and opinion.

\section{Justice, Though Fundamental, is Neither the Sole nor the Ultimate Value}

If one were to poll contemporary sociologists in the United States about their values and priorities, many would very likely cite "justice" as the primary concern. The concept of justice, of course, is many-sided, but when sociologists use it they tend to mean distributive justice, that is, the fair and equitable allocation of resources. There is less apparent concern with the productive side of justice (even though the famous Marxist formula, "from each according to ability, to each according to need," recognizes it). In daily living, sociologists often recognize the productive aspect of justice, as when poorly performing members of academic departments receive the same "across the board" pay raises as others who are making outstanding contributions in the classroom, in research and in service.

In my early education in the Catholic world, justice was presented as a primary virtue and thus a fundamental good. But it was never divorced from other virtues. Indeed, the teaching was that the virtues (e.g., justice, temperance, fortitude, prudence) could only be understood holistically, in relation to one another. The ultimate virtue was love (willing and seeking the good of the other), which also meant that justice was one aspect of love. These principles still seem to me fundamentally sound, even within a social scientific as opposed to a religious setting. Interestingly, we have seen this reaffirmed in the past decade and a half in psychology, especially in the work of Martin Seligman and the late Christopher Peterson (2004), who were early leaders of the now influential movement to create a "positive psychology."

An interesting question is this: What motivates us to seek justice? There are many possibilities. On the positive side, we might answer that empathy, compassion and love 
are the driving forces. But the quest for justice can also arise from negative sources, such as jealousy, envy, resentment and hatred. From this perspective, justice can be understood as "an eye for an eye" (which as Gandhi and Dr. Martin Luther King asserted, makes the whole world blind), or "evening the score" or exacting vengeance. We see this around the globe today, often in the violence that arises from chronic conflicts rooted in ethnic and racial relations, or in economic divisions, or in religious differences, or in clashes of culture more generally. The late Osama bin Laden, as well as other members of Al Qaeda and similar groups, argued that a million Americans, including many thousands of children, deserved to die in order to satisfy the demands of justice, to compensate for the suffering the United States has perpetrated in the Middle East, especially in Islamic countries.

Therefore, if we seek to build the "good society" or to promote "new visions of human flourishing" (the theme for the 2015 conference of the North Central Sociological Association), we need to recognize that justice, by itself, is not enough. In order to be truly beneficial, it must be rooted in empathy and compassion and a commitment to non-violence. It must be, in other words, an expression of love.

Within sociology, the quest for justice has been linked to a discourse of "equality and inequality." I believe that Christian Smith is correct in asserting that, for many in the field, activism on behalf of equality has become a "sacred project" that cannot be questioned. I think it is also fair to say that many contemporary departments of sociology are tending to evolve toward "departments of inequality studies." In the same way, professional conferences in the field, at both the regional and national levels, select themes related to equality-inequality more frequently than any other topic. The impression this gives is that this is the only issue that unites the discipline.

Nevertheless it is a logical error to identify justice with either equality or inequality, and consequently to idealize the one and vilify the other. In some cases, justice does indeed demand equality, which may refer to equality of opportunity or equality of outcome, or both. In other cases, however, justice demands inequality. Where rewards are performance based, higher effort and higher achievement should receive more. In practice, everyone recognizes this. No one would, for instance, give equal grades to students who scored 95, 75 and 55 on an exam. Nor would sociologists in general support the notion that everyone should receive a distinguished scholarly teaching or research award, or a distinguished career award, or be elevated to a leadership position in a professional association. They would accept the view that justice demands that such rewards be given to those with outstanding records. They would accept meritbased inequality.

There was a time when inequality was rather celebrated in the field of sociology, often in naive ways. Among the most prominent historical examples was the article on a functional approach to stratification, written by Kingsley Davis and Wilbert E. Moore and published in the mid-1940s. These authors argued that all human groups find it necessary to reward performance differentially, and to give more to those who contribute more to the group's needs. They asserted further that members of groups would not be motivated to take on the most difficult tasks, especially those requiring long and specialized training, if there were not some payoff for making the effort and the sacrifice. Although Davis and Moore did not use the term "justice," many felt that their analysis implied that inequality, in general, was just. 
Such an identification was, and would be, a mistake. But sociology does not benefit by making the opposite mistake and treating equality as synonymous with justice. Sooner or later this needs to be recognized, and the complex relations between justice, equality and inequality need to be sorted out in new ways.

\section{Sociology Needs to Become More "Integral" and to Embrace Spirituality}

Humans seem to have a strong tendency to dichotomize. Pitirim Sorokin implied this in his major work, Social and Cultural Dynamics which traced fluctuations of spiritual and secular cultures over twenty-five centuries. More recently, as noted above, we have witnessed a shift from the hegemony of a consensus perspective to that of a conflict approach. Must we choose between these, or can we develop a more holistic or "integral" approach (as Sorokin advocated, both in sociology, and in the larger social and cultural field).

It has been said that "every way of seeing is also a way of not seeing." When we focus our "sociological eye" (in Everett C. Hughes's phrase) only on cooperation, we fail to notice tensions and conflicts, exploitation and oppression, or ways in which group life is rigged in favor of those already enjoying high status. In the same way, when our eye notices only conflict we see a world of total victimization, and miss the pro-social and the beneficial. This also makes it difficult to deal with "mixed cases," where groups engage both in positive and negative behaviors. The sociological literature, for instance, is pervaded with critiques of "corporations," meaning especially forprofit corporations. Such critiques are produced by sociologists seated in chairs manufactured by corporations, who turn on corporate-made computers to formulate their thoughts which they might also share on corporate-made phones, and who board corporate-built jets to travel to corporate-owned hotels where they deliver their papers, all the while employed by universities that are increasingly dependent on corporate support. But none of these positives is generally mentioned. The emphasis instead is on corporate crime, or the increasing inequality between the "compensation packages" of top managers and the pay and benefits of average workers. Thus, there is condemnation, but there is little or no room for praise. And to the extent that sociologists are "in the business of critique," we are in the business of producing partial truths based on political ideology, and not "the whole truth" that I believe science, as well as a sense of fundamental fairness, requires.

I therefore believe that a holistic approach is the way forward for our discipline, and the best statement of that which I have found is Pitirim A. Sorokin's "Integralism," which calls for a reunification of the true, the beautiful and the good, as well as the spiritual and secular aspects of life (Sorokin 1966; Nichols 2006). In this connection, it is interesting to note the emergence of a "discourse of spirituality" across a range of fields, including medicine (Koenig 2008; Young and Koopsen 2009), end-of-life caregiving (Gilbert 2013), and even business (Aburdene 2007; Mackey and Sisodia 2013).. As sociologists of religion have recognized (e.g., Krause 2014), "spirituality" is not identical with religiosity, and many of those promoting a spiritual point of view are not personally involved with organized religion (Fuller 2001; Ammerman 2013). I consider the spreading discourse of spirituality to be a very important development, and one that is likely to become even more significant in the decades ahead. 
To return to a question raised earlier, What motivates us to seek justice? Is it anger, envy, jealousy, resentment, a desire for vengeance, and is it thus merely personal or political? Or is it something more noble, that comes from our deepest desire to do good? In the latter case, I think it could legitimately be termed a spiritual quest, in the sense of something that transcends the merely personal and the merely political. This would be the view of a Mohandas Gandhi, a Jane Addams, a Dr. Martin Luther King, Jr., or a Mother Teresa, a Cesar Chavez and a Nelson Mandela. For all of these champions of justice, politics only has value insofar as it is situated within a larger, non-political framework for which, I would argue, the best word that we have is "spiritual." This is the ultimate ground of human bonding and of human equality.

If we choose to operate from such a perspective, we can produce a different type of sociology. We can create a "sociology of love" (Sorokin 1954) that will complement our studies of hate and violence and warfare. Indeed, studies of altruism and pro-social behavior have already attained respectability and wide influence (Jeffries 2014). I have tried to make some modest contributions to this effort through my own research (Nichols 2014) and through my editorial work with this journal. The recent proposal to develop a sociology based on Buddhist principles (Schipper 2012) likewise expresses the possibilities of incorporating a spiritual perspective throughout the field.

Ultimately, the challenge is to do sociology with love. This includes our relations with students, with colleagues in academic departments and in our field more generally, as well as with the various "publics" we serve. It will require great patience and tolerance for diverse points of view, as well as a willingness to forgive and to be reconciled. It will not be easy. But it is the only future worth pursuing.

\section{References}

Aburdene, P. (2007). Megatrends 2010: The rise of conscious capitalism. New York: Hampton Roads Publishing.

Ammerman, N. T. (2013). Spiritual but not religous? Beyond binary choices in the study of religion. Journal for the Scientific Study of Religion, 52(2), 258-278.

Becker, H. S. (1967). Whose side are we on? Social Problems, 14(3), 239-247.

Burawoy, M. (2005). For public sociology. American Sociological Review, 70(1), 4-28.

Deegan, M. J. (1990). Jane Addams and the men of the Chicago school, 1892-1918. New Brunswick: Transaction Publishers.

Feagin, J. R., \& Vera, H. (2008). Liberation sociology. New York: Paradigm.

Fuller, R. C. (2001). Spiritual but not religious: Understanding unchurched America. Boston: Beacon.

Garfinkel, H. (1956). Conditions of successful degradation ceremonies. American Sociological Review, 61(5), $420-424$.

Gilbert, P. (2013). Spirituality and end of life care: A handbook for users, careers and staff wishing to bring a spiritual dimension to mental health services. New York: Pavilion Publishing.

Goffman, E. (1959). The presentation of self in everyday life. Garden City: Doubleday.

Hill, M. R., \& Drysdale, S. H. (Eds.). (2003). Harriet Martineau: Theoretical and methodological perspectives. New York: Routledge.

Jeffries, V. (Ed.). (2014). The Palgrave handbook of altruism, morality and social solidarity. New York: Palgrave Macmillan.

Koenig, H. G. (2008). Medicine, religion and health: Where science and spirituality meet. New York: Templeton Press.

Krause, R. (2014). Transforming spirituality in artistic leisure: How the spiritual meaning of belly dance changes over time, Journal for the Scientific Study of Religion, 53(3), 459-478. 
Lengerman, P. M., \& Brantley, J. N. (1997). The women founders: Sociology and social theory, 1830-1930. New York: McGraw Hill.

Mackey, J., \& Sisodia, R. (2013). Conscious capitalism: Liberating the heroic spirit of business. Cambridge: Harvard Business School Review Press.

Merton, R. K. (1973). The sociology of science. Chicago: University of Chicago Press.

Nichols, L. T. (2006). The diversity of Sorokin's integralism: Eastern, western, christian and non-christian variants. In E. Del Pozo Avino (Ed.), Integralism, altruism and reconstruction: Essays in honor of Pitirim A. Sorokin (pp. 59-69). Valencia: Univesitat de Valencia Press.

Nichols, L. T. (2012). Renewing sociology: integral science, solidarity and loving kindness. Sociological Focus, 45(4), 261-273.

Nichols, L. T. (2014). Modern roots of the sociology of love: Tolstoy, Addams, Gandhi and Sorokin. In V. Jeffries (Ed.), The Palgrave handbook of altruism, morality and social solidarity (pp. 149-175). New York: Palgrave Macmillan.

Peterson, C., \& Seligman, M. (2004). Character strengths and virtues. New York: Oxford University Press.

Schipper, J. (2012). Toward a Buddhist sociology: theories, methods, and possibilities. The American Sociologist, 43(2), 203-222.

Smith, C. (2014). The sacred project of American sociology. New York: Oxford Univesity Press.

Sorokin, P. A. (1954). The ways and power of love. Boston: Beacon.

Sorokin, P. A. (1966). Sociological theories of today. New York: Harper.

Turner, S. P. (2013). American sociology. New York: Palgrave Macmillan.

Weber, M. 1946 (1922). Science as a vocation. In H. Gerth, C. W. Mills (Eds.), From Max Weber: essays in sociology (pp. 129-156). New York: Oxford University Press.

Young, C., \& Koopsen, C. (2009). Spirituality, health and healing: An integrative approach. New York: Jones and Bartlett Learning. 